\title{
OPTIMALISASI TEKNIK ISOLASI DAN PURIFIKASI DNA MENGGUNAKAN BUFFER CTAB (CETYLTRIMETHYL AMMONIUM BROMIDE) PADA TANAMAN MARKISA (Passiflora sp.) DATARAN RENDAH KABUPATEN JENEPONTO
}

\author{
Optimization of The DNA Isolation and Purification Using CTAB Buffer \\ (Cetyl Trimethyl Ammonium Bromide) In Passion Fruit Plants (Passiflora sp.) \\ On Lowland of Jeneponto District
}

\author{
A. Farhanah ${ }^{1}$, Jabal R. Ashar ${ }^{2}$, dan P. Hamzah ${ }^{1}$ \\ ${ }^{1}$ Jurusan Pertanian Politeknik Pembangunan Pertanian Gowa \\ ${ }^{2}$ Fakultas Pertanian Universitas Muslim Indonesia \\ e-mail: difarhanah@yahoo.co.id
}

Received: 6 April 2021; Accepted: 26 Mei 2021; Published: 25 Juni 2021

\begin{abstract}
ABSTRAK
Penelitian ini bertujuan untuk mendapatkan prosedur metode CTAB dan metode purifikasi DNA yang tepat untuk menghasilkan kuantitas dan kualitas DNA yang baik yang berasal dari tanaman markisa dataran rendah. Penelitian ini dilaksanakan di dua tempat, yaitu kabupaten Jeneponto untuk pengambilan sampel tanaman markisa dan untuk pengisolasian dan pengujian DNA dilakukan di Laboratorium Biosains dan Sumber Daya Hayati Tanaman Program Studi Agroteknologi Jurusan Budidaya Pertanian Fakultas Pertanian Universitas Hasanuddin Makassar. Penelitian ini berlangsung dari bulan September 2013 hingga Desember 2013. Penelitian dilaksanakan dalam enam metode isolasi DNA dengan menggunakan larutan CTAB, pengujian kualitas serta kuantitas DNA, pemurnian (purifikasi) DNA pada hasil isolasi terbaik, dan pengujian kualitas serta kuantitas pada hasil pemurnian. Berdasarkan uji kualitas dan kuantitas, berat sampel sebesar $0,200 \mathrm{~g}$, suhu inkubasi hasil ekstraksi pada suhu $65^{\circ} \mathrm{C}$ selama 30 menit, dan kecepatan sentrifugasi sebesar $12.000 \mathrm{rpm}$ selama 10 menit dapat menghasilkan DNA yang memiliki kemurnian yang cukup baik dan tampak pita DNA yang cukup tebal berkisar 1500 - 5000 kb setelah hasil isolasi DNA dielektroforesis. Sedangkan pemurnian kembali menggunakan kloroform: isoamylalkohol, isopropanol, dan ethanol 70\% menunjukkan kualitas dan kuantitas DNA yang baik.
\end{abstract}

Kata kunci: Markisa, dataran rendah, CTAB, isolasi DNA, kualitas dan kuantitas

\begin{abstract}
This study aims to obtain the proper CTAB method and DNA purification method to produce good quantity and quality of DNA originating from lowland passion fruit. This research was conducted in two places, namely Jeneponto district for sampling of passion fruit plants and for DNA isolation and testing carried out at the Laboratory of Bioscience and Plant Biological Resources Study Program of Agrotechnology Department of Agriculture, Hasanuddin University, Makassar. This research held from September 2013 to December 2013. The research was carried out in six DNA isolation methods using CTAB solution, testing the quality and quantity of DNA, purification of DNA on the best isolation results, and testing the quality and quantity of the purification results. Based on the quality and quantity test, the sample weight was 0.200 $g$, the extracted incubation temperature at $650 \mathrm{C}$ for 30 minutes, and a centrifugation speed of 12,000 rpm for 10 minutes could produce DNA that had a fairly good purity and a thick enough DNA band was around
\end{abstract}


1500 - $5000 \mathrm{~kb}$ after the results of electrophoresis of the DNA. Meanwhile, purification using chloroform: isoamyl alcohol, isopropanol, and ethanol 70\% showed good quality and quantity of DNA.

\section{Keywords: Passion fruit, lowland, CTAB, DNA isolation, quality and quantity}

\section{PENDAHULUAN}

Ketersediaan varietas unggul, baik mutu, produktivitas, maupun ketahanannya terhadap hama-penyakit dan cekaman lingkungan, serta yang sesuai dengan kebutuhan konsumen, menjadi syarat yang harus dipenuhi pada era industrialisasi pertanian dan liberalisasi perdagangan. Tanaman buah diharapkan menjadi pertumbuhan baru di sektor pertanian, maka upaya menghasilkan komoditas buah-buahan unggul bermutu tinggi dengan keunggulan kompetitif tinggi dan potensi hasil tinggi harus menjadi landasan kerja yang utama saat ini. Varietas yang unggul dapat dirakit jika tersedia sumberdaya genetik yang mempunyai karakter sesuai dengan yang dikehendaki (Karsinah et al., 2007).

Penelitian keragaman genetik tanaman buah merupakan salah satu kegiatan penting untuk mendukung pemuliaan tanaman. Perbedaan tanaman dapat dideteksi melalui beberapa penanda, antara lain dengan pola pita DNA (Lamadji 1998), yang sering disebut sebagai penanda molekuler. Penanda molekuler berperan penting dalam konservasi dan pengelolaan sumber daya genetik tanaman (Karp et al. 1997).

Beberapa teknik dan prosedur telah dipublikasikan, tetapi seringkali tidak dapat diaplikasikan karena genus atau bahkan spesies tanaman bersifat sangat spesifik. Modifikasi metode standar ekstraksi DNA diperlukan pada ekstraksi DNA dari daun tanaman yang mengandung banyak polisakarida atau metabolit sekunder. Ekstraksi DNA daun tanaman Grevillea (Proteaceae) dengan memodifikasi metode Doyle dan Doyle (1990), telah berhasil memperoleh DNA dengan kualitas yang baik (Pharmawati, 2009). Metode isolasi DNA tanaman bitti (Vitex cofassus) dengan menggunakan metode Lengkong et al. (1998) dalam Masniawati (2000) berdasarkan penelitian Pratama (2009) memperlihatkan hasil ekstraksi DNA yang kurang optimal baik kualitas maupun kuantitas DNA yang dihasilkan sehingga mempengaruhi intensitas pita DNA hasil amplifikasi yang tidak jelas. Hal tersebut menunjukkan bahwa metode isolasi DNA yang telah dilakukan pada tanaman padi tidak dapat diaplikasikan secara maksimal pada tanaman lain khususnya jenis tanaman kehutanan.

Meskipun isolasi DNA dapat dilakukan dengan berbagai cara, akan tetapi pada setiap jenis atau bagian tanaman dapat memberikan hasil yang berbeda, hal ini dikarenakan adanya senyawa polifenol dan polisakarida dalam konsentrasi tinggi yang dapat menghambat pemurnian DNA. Jika isolasi DNA dilakukan dengan sample buah, maka kadar air pada masing-masing buah berbeda, dapat memberi hasil yang berbeda-beda pula. Semakin tinggi kadar air, maka sel yang terlarut di dalam ekstrak akan semakin sedikit, sehingga DNA yang terpresipitasi juga akan sedikit (Fatchiyah, 2006).

DNA berkualitas tinggi yang akan didapat dalam suatu ekstraksi merupakan satu kaidah dasar yang harus dipenuhi dalam studi molekuler, terutama dalam penandaan sidik jari DNA. Cetyl Trimethyl Ammonium Bromide (CTAB) merupakan metode yang umum digunakan dalam ekstraksi DNA tanaman yang banyak mengandung polisakarida dan senyawa polifenol (JOSE dan USHA, 2000 dalam Ardiana, 2009). Ada tiga langkah utama dalam ekstraksi

DNA, yaitu perusakan dinding sel (lisis), pemisahan DNA dari bahan padat seperti selulosa dan protein, serta pemurnian DNA (Surzycki, 2000 dalam Ardiana, 2009).

Larutan CTAB (Cetyltrimethyl Ammonium Bromide) dapat melarutkan membran plasma dan akan membentuk komplek dengan DNA. Salah satu keunggulan metode ini adalah tidak dibutuhkannya persiapan yang panjang untuk jaringan tanaman dan dapat digunakan untuk berbagai jenis jaringan termasuk daun, akar, biji, embrio, endosperma dan pollen serta kultur suspensi (Chawla, 2003)..

Markisa merupakan tanaman buahbuahan yang tumbuh dan hampir ada di seluruh Indonesia. Negara Indonesia merupakan salah satu negara penghasil buah markisa di Asia. Markisa termasuk dalam famili Passifloraceae yang berasal dari Amerika Selatan. Jenis markisa yang dibudidayakan di Indonesia meliputi markisa asam dengan kulit berwarna ungu yang 
disebut siuh atau purple passion fruit ( $P$. edulis f. edulis Sims), markisa asam dengan kulit buah berwarna kuning disebut juga rola atau yellow passion fruit ( $P$. edulis Sims f. flavicarpa Deg.), markisa konyal atau markisa manis $(P$. ligularis Juss), dan erbis atau giant granadilla ( $P$. quadrangularis L.). Markisa asam berkulit buah ungu hanya dapat tumbuh dan berkembang baik di daerah subtropis dan dataran tinggi tropis, sedangkan jenis kuning dapat beradaptasi di dataran rendah tropis (Winks et al., 1998 dalam Rukmana, 2003). Sentra produksi buah markisa di Indonesia adalah Sumatera Utara (Karo dan Simalungun), dan Sulawesi Selatan (Gowa, Tanah Toraja, Sinjai, Enrekang, dan PolewaliMamasa) (Barus dan Syukri, 2008). Bahkan saat ini markisa telah di kembangkan lagi di daerah dataran rendah, kabupaten Jeneponto, Sulawesi Selatan.

Berdasarkan penjelasan di atas, maka dilakukan penelitian mengenai optimalisasi teknik isolasi dan purifikasi DNA menggunakan buffer CTAB (Cetyltrimethyl Ammonium Bromide) pada tanaman markisa dataran rendah kabupaten Jeneponto. Penelitian ini bertujuan mendapatkan prosedur metode $\mathrm{CTAB}$ yang tepat untuk menghasilkan kuantitas dan kualitas DNA yang baik pada tanaman markisa dataran rendah.

\section{METODE PENELITIAN}

Pengambilan sampel dilakukan di kabupaten Jeneponto, sedangkan isolasi dan pengujian DNA dilakukan di laboratorium Biosains dan Sumber Daya Hayati Tanaman Program Studi Agroteknologi Jurusan Budidaya Pertanian Fakultas Pertanian Universitas Hasanuddin.

Penelitian ini dilakukan menggunakan beberapa prosedur isolasi DNA dengan menggunakan larutan $\mathrm{CTAB}$, pengujian kualitas serta kuantitas DNA, pemurnian (purifikasi) DNA pada hasil isolasi terbaik, dan pengujian kualitas serta kuantitas pada hasil pemurnian. Bahan yang digunakan adalah sampel daun tanaman sehat markisa dataran rendah Jeneponto, $2 \%$ CTAB, $P V P$, es cacah, EDTA, $\mathrm{NaCl}, \mathrm{dH}_{2} \mathrm{O}$ steril, $\quad \beta$-merkaptoethanol, $\quad$ chloroform isoamylalkohol (CI), isopropanol, TE buffer, TBE (Tris Borate EDTA), ethanol 70\%, Ethidium Bromide, agarose, tubes, dan tips. Alat yang digunakan adalah mortar and pestle, gunting, timbangan analitik, vortex, sentrifugator, pipet tetes mikro, waterbath, lemari pendingin, nano spectrophotometer, elektroforesis, Gel document.

\section{Pengambilan Sampel Tanaman}

Sampel tanaman markisa sehat diambil dari kabupaten Jeneponto. Pengambilan sampel dilakukan dengan melihat fisiologi tanaman markisa yang berbeda-beda khususnya pada warna kulit buah markisa.

\section{Isolasi DNA}

DNA genomik akan diisolasi dari jaringan daun tanaman markisa berdasarkan metode Doyle \& Doyle (1990). Dalam metode Doyle \& Doyle (1990), isolasi DNA tanaman menggunakan larutan $\mathrm{CTAB}$ dengan campuran Carlson buffer lysis (100mM Tris pH 9,5 (1,21 g Tris dalam $70 \mathrm{~mL}$ ddH2O), $20 \mathrm{mM}$ EDTA $(0,76$ g), $1,4 \mathrm{M} \mathrm{NaCl}(8,18 \mathrm{~g}), 2 \%$ CTAB (2 gr), $1 \%$ PEG 8000 atau $6000(1 \mathrm{~g}))$ sebanyak $4 \mathrm{~mL}$, PVP 0,08 gram, dan $\beta$-merkaptoethanol sebanyak 8 $\mu \mathrm{L}$. Campuran tersebut divortex, lalu dipanaskan selama 30-60 menit pada $65-75^{\circ} \mathrm{C}$.

Masing-masing sampel tanaman ditimbang terlebih dahulu. Berat masing-masing sampel tanaman diambil dengan berat $0,10-0,20$ gram (lihat tabel 1). Masing-masing sampel tadi digerus kemudian masing-masing ditambahkan larutan CTAB sebanyak $750 \mu \mathrm{L}$, lalu masingmasing dimasukkan ke dalam tube yang steril lalu dibolak-balik secara perlahan. Setelah itu, masing-masing tube yang diisi tadi diinkubasi dalam waterbath pada suhu $65^{\circ}-75^{\circ} \mathrm{C}$ selama $30-$ 45 menit (setiap 10 menit semua tube dibolakbalik secara perlahan) (lihat tabel 1). Setelah itu, semua tube tadi disentrifugasi pada suhu ruang dengan kecepatan $10.000 \mathrm{rpm}$ hingga $12.000 \mathrm{rpm}$ dengan dalam waktu 10 menit (lihat tabel 1).

Masing-masing supernatant dipindahkan ke dalam masing-masing tube baru yang steril lalu masing-masing supernatant ditambahkan chloform-isoamylalcohol (24:1) sebanyak volume supernatant. Kemudian tube yang berisi supernatant dan chloform-isoamylalcohol (24:1) tadi dibolak-balik secara perlahan hingga 100 kali lalu disentrifugasi pada suhu ruang dengan kecepatan $10.000 \mathrm{rpm}$ hingga $12.000 \mathrm{rpm}$ (lihat tabel 1) dengan dalam waktu 10 - 15 menit (lihat tabel 1) Supernatan hasil sentrifugasi dipindahkan kembali ke tube baru. Kemudian ditambahkan dengan isopropilalkohol sebanyak volume supernatant. Kemudian disentrifugasi pada suhu $4^{\circ} \mathrm{C}$ dengan kecepatan $10.000 \mathrm{rpm}$ 
hingga $12.000 \mathrm{rpm}$ (lihat tabel 1) dengan dalam waktu 10 - 15 menit (lihat tabel 1).

Cairan hasil sentrifugasi sentrifugasi (supernatant) dibuang perlahan, sedangkan masing-masing pellet ditambahkan dengan Etanol $70 \%$ dingin sebanyak $200 \mu \mathrm{L}$ lalu dicampur dengan cara mengetuk-ngetuk tube berulang-ulang. Kemudian disentrifugasi pada suhu suhu $4^{\circ} \mathrm{C}$ dengan kecepatan $10.000 \mathrm{rpm}$ hingga $12.000 \mathrm{rpm}$ (lihat tabel 1) selama 5 menit. Cairan hasil sentrifugasi (supernatant) dibuang perlahan, sedangkan masing-masing pellet ditambahkan dengan etanol 70\% dingin sebanyak $200 \mu \mathrm{L}$ namun tidak dicampur. Kemudian disentrifugasi pada suhu $4^{\circ} \mathrm{C}$ dengan kecepatan $10.000 \mathrm{rpm}$ hingga $12.000 \mathrm{rpm}$ (lihat tabel 1) selama 2 menit. Pellet dikeringkan selama 1-2 jam dengan cara membalikkan tube. Setelah pellet kering, pellet ditambahkan dengan larutan TE buffer sebanyak $50 \mu \mathrm{L}$. Kemudian tube tersebut di simpan dalam freezer.

Tabel 1. Tabel optimasi isolasi DNA menggunakan larutan buffer CTAB pada tanaman markisa dataran rendah kabupaten Jeneponto

\begin{tabular}{cccccccccccc}
\hline \multirow{2}{*}{ Protokol } & $\begin{array}{c}\text { Berat Sampel } \\
(\text { gram })\end{array}$ & \multicolumn{2}{c}{$\begin{array}{c}\text { Suhu inkubasi } \\
\left({ }^{\circ} \mathrm{C}\right)\end{array}$} & \multicolumn{2}{c}{$\begin{array}{c}\text { Lama inkubasi } \\
(\text { menit })\end{array}$} & $\begin{array}{c}\text { Kecepatan } \\
\text { sentrifugasi } \\
(\text { x 100 rpm) }\end{array}$ & $\begin{array}{c}\text { Lama } \\
\text { sentrifugasi } \\
(\text { menit })\end{array}$ \\
\cline { 2 - 14 } & 0,15 & 0,2 & 65 & 75 & 20 & 30 & 45 & 100 & 120 & 10 & 15 \\
\hline A & $\sqrt{ }$ & - & $\sqrt{ }$ & - & - & - & $\sqrt{ }$ & $\sqrt{ }$ & - & $\sqrt{ }$ & - \\
B & - & $\sqrt{ }$ & $\sqrt{ }$ & - & - & - & $\sqrt{ }$ & $\sqrt{ }$ & - & $\sqrt{ }$ & - \\
C & $\sqrt{ }$ & - & - & $\sqrt{ }$ & $\sqrt{ }$ & - & - & $\sqrt{ }$ & - & $\sqrt{ }$ & - \\
D & $\sqrt{ }$ & - & $\sqrt{ }$ & - & - & $\sqrt{ }$ & - & - & $\sqrt{ }$ & - & $\sqrt{ }$ \\
E & $\sqrt{ }$ & - & $\sqrt{ }$ & - & - & $\sqrt{ }$ & - & - & $\sqrt{ }$ & $\sqrt{ }$ & - \\
F & - & $\sqrt{ }$ & $\sqrt{ }$ & - & - & $\sqrt{ }$ & - & - & $\sqrt{ }$ & $\sqrt{ }$ & - \\
\hline
\end{tabular}

\section{Uji Kualitas dan Kuantitas Hasil Ekstraksi DNA Markisa}

Pengujian kuantitas DNA dilakukan dengan menggunakan nanospektrophotometer. Nilai rasio serapan $\lambda 260 / 230$ lebih besar 1 murni dan nilai $1,8-2,0$ pada rasio serapan $\lambda 260 / 280$ dianggap murni. Pengujian kualitas DNA juga dilakukan dengan menggunakan alat elektroforesis dan gel document untuk melihat pita DNA yang ada.

\section{Pemurnian DNA Markisa}

Pemurnian dilakukan pada sampel yang menunjukkan kualitas dan kuantitas DNA yang baik dengan penambahan chloformisoamylalcohol (24:1) sebanyak $50 \mu \mathrm{L}$ ke dalam tube yang berisi hasil isolasi DNA yang telah dielektroforesis, kemudian dibolak-balik secara perlahan hingga 100 kali lalu disentrifugasi pada suhu ruang dengan kecepatan 12.000 rpm dengan dalam waktu 10 menit. Supernatan hasil sentrifugasi dipindahkan kembali ke tube baru. Kemudian ditambahkan dengan isopropilalkohol sebanyak volume supernatant. Kemudian disentrifugasi pada suhu $4^{\circ} \mathrm{C}$ dengan kecepatan $14.000 \mathrm{rpm}$ dengan dalam waktu 10 menit. Cairan hasil sentrifugasi dibuang perlahan, sedangkan masing-masing pellet ditambahkan dengan Etanol $70 \%$ dingin sebanyak $50 \mu \mathrm{L}$ namun tidak dicampur. Kemudian disentrifugasi pada suhu suhu $4^{\circ} \mathrm{C}$ dengan kecepatan 12.000 selama 2 menit. Pellet dikeringkan selama 1-2 jam dengan cara membalikkan tube. Setelah pellet kering, pellet ditambahkan dengan larutan TE buffer sebanyak $25 \mu \mathrm{L}$. Bahan siap digunakan untuk dielektroforesis.

\section{Uji Kualitas dan Kuantitas Hasil Pemurnian DNA Markisa}

Pengujian kualitas dan kuantitas hasil pemurnian DNA markisa dilakukan sama halnya pengujian kualitas dan kuantitas hasil ekstraksi DNA markisa

\section{HASIL DAN PEMBAHASAN}

Berdasarkan metode di atas, maka diperoleh hasil seperti di Tabel 2. 
Tabel 2. Hasil uji kualitas dan kuantitas hasil isolasi DNA tanaman markisa dataran rendah Kabupaten Jeneponto menggunakan nanospektrofotometri

\begin{tabular}{|c|c|c|c|c|c|c|}
\hline \multirow{2}{*}{$\begin{array}{l}\text { Metode } \\
\text { Ekstraksi }\end{array}$} & \multirow{2}{*}{ Sampel } & \multicolumn{2}{|c|}{ Rasio Serapan } & \multirow{2}{*}{$\begin{array}{l}\text { Konsentrasi } \\
(\mu \mathrm{g} / \mathrm{mL})\end{array}$} & \multicolumn{2}{|c|}{$\begin{array}{c}\text { Tingkat Kemurnian } \\
\text { DNA }\end{array}$} \\
\hline & & A260/280 & A260/230 & & Murni & Tidak Murni \\
\hline \multirow{9}{*}{ A } & 1 & 1,421 & 0,872 & 26,9 & - & $\sqrt{ }$ \\
\hline & 2 & 1,714 & 1,132 & 23,9 & - & $\sqrt{ }$ \\
\hline & 3 & 1,630 & 0,914 & 21,9 & - & $\sqrt{ }$ \\
\hline & 4 & 1,524 & 0,815 & 31,9 & - & $\sqrt{ }$ \\
\hline & 5 & 1,697 & 1,013 & 27,9 & - & $\sqrt{ }$ \\
\hline & 6 & 1,842 & 1,272 & 186 & $\sqrt{ }$ & - \\
\hline & 7 & 1,383 & 0,886 & 126 & - & $\sqrt{ }$ \\
\hline & 8 & 1,536 & 0,987 & 42,8 & - & $\sqrt{ }$ \\
\hline & 9 & 1,547 & 1,316 & 40,8 & - & $\sqrt{ }$ \\
\hline \multirow{9}{*}{ B } & 1 & 1,521 & 0,178 & 31,2 & - & $\sqrt{ }$ \\
\hline & 2 & 1,209 & 0,213 & 15,9 & - & $\sqrt{ }$ \\
\hline & 3 & 1,607 & 0,218 & 22,4 & - & $\sqrt{ }$ \\
\hline & 4 & 1,619 & 0,169 & 16,9 & - & $\sqrt{ }$ \\
\hline & 5 & 1,870 & 0,212 & 50,3 & $\sqrt{ }$ & - \\
\hline & 6 & 1,256 & 0,246 & 24,4 & - & $\sqrt{ }$ \\
\hline & 7 & 1,194 & 0,397 & 138 & - & $\sqrt{ }$ \\
\hline & 8 & 1,358 & 0,365 & 174 & - & $\sqrt{ }$ \\
\hline & 9 & 1,556 & 0,256 & 101 & - & $\sqrt{ }$ \\
\hline \multirow{9}{*}{$\mathrm{C}$} & 1 & 1,353 & 0,731 & 30,9 & - & $\sqrt{ }$ \\
\hline & 2 & 1,242 & 0,983 & 21,4 & - & $\sqrt{ }$ \\
\hline & 3 & 1,721 & 0,235 & 20,8 & - & $\sqrt{ }$ \\
\hline & 4 & 1,134 & 0,692 & 15,2 & - & $\sqrt{ }$ \\
\hline & 5 & 0,971 & 0,715 & 18,4 & - & $\sqrt{ }$ \\
\hline & 6 & 1,675 & 0,892 & 20,6 & - & $\sqrt{ }$ \\
\hline & 7 & 1,542 & 0,119 & 90,2 & - & $\sqrt{ }$ \\
\hline & 8 & 1,172 & 0,891 & 108 & - & $\sqrt{ }$ \\
\hline & 9 & 0,914 & 0,429 & 50,3 & - & $\sqrt{ }$ \\
\hline \multirow{9}{*}{$\mathrm{D}$} & 1 & 1,423 & 0,312 & 1923 & - & $\sqrt{ }$ \\
\hline & 2 & 1,321 & 1,133 & 2506 & - & $\sqrt{ }$ \\
\hline & 3 & 0,981 & 1,225 & 1392 & - & $\sqrt{ }$ \\
\hline & 4 & 1,498 & 2,13 & 1324 & - & $\sqrt{ }$ \\
\hline & 5 & 2,198 & 1,428 & 1763 & - & $\sqrt{ }$ \\
\hline & 6 & 1,219 & 0,913 & 1988 & - & $\sqrt{ }$ \\
\hline & 7 & 1,823 & 0,235 & 2897 & $\sqrt{ }$ & - \\
\hline & 8 & 2,321 & 3,213 & 938 & - & $\sqrt{ }$ \\
\hline & 9 & 1,398 & 0,875 & 2931 & - & $\sqrt{ }$ \\
\hline
\end{tabular}




\begin{tabular}{|c|c|c|c|c|c|c|}
\hline \multirow{2}{*}{$\begin{array}{l}\text { Metode } \\
\text { Ekstraksi }\end{array}$} & \multirow{2}{*}{ Sampel } & \multicolumn{2}{|c|}{ Rasio Serapan } & \multirow{2}{*}{$\begin{array}{c}\text { Konsentrasi } \\
(\mu \mathrm{g} / \mathrm{mL})\end{array}$} & \multicolumn{2}{|c|}{$\begin{array}{c}\text { Tingkat Kemurnian } \\
\text { DNA }\end{array}$} \\
\hline & & A260/280 & A260/230 & & Murni & Tidak Murni \\
\hline \multirow{9}{*}{$\mathrm{E}$} & 1 & 1,333 & 1,397 & 213 & - & $\sqrt{ }$ \\
\hline & 2 & 2,267 & 1,759 & 986 & - & $\sqrt{ }$ \\
\hline & 3 & 1,967 & 1,381 & 1715 & $\sqrt{ }$ & - \\
\hline & 4 & 1,233 & 1,031 & 2903 & - & $\sqrt{ }$ \\
\hline & 5 & 1,616 & 1,022 & 3143 & - & $\sqrt{ }$ \\
\hline & 6 & 1,739 & 1,313 & 790 & - & $\sqrt{ }$ \\
\hline & 7 & 1,668 & 1,264 & 3087 & - & $\sqrt{ }$ \\
\hline & 8 & 1,178 & 0,979 & 3106 & - & $\sqrt{ }$ \\
\hline & 9 & 0,939 & 0,937 & 3473 & - & $\sqrt{ }$ \\
\hline \multirow{9}{*}{$\mathrm{F}$} & 1 & 1,651 & 1,136 & 1874 & - & $\sqrt{ }$ \\
\hline & 2 & 1,568 & 1,293 & 2761 & - & $\sqrt{ }$ \\
\hline & 3 & 1,868 & 1,370 & 1466 & $\sqrt{ }$ & - \\
\hline & 4 & 2,625 & 3,247 & 761 & - & $\sqrt{ }$ \\
\hline & 5 & 1,859 & 1,663 & 2447 & $\sqrt{ }$ & - \\
\hline & 6 & 0,688 & 0,913 & 1546 & - & $\sqrt{ }$ \\
\hline & 7 & 1,902 & 1,517 & 2572 & $\sqrt{ }$ & - \\
\hline & 8 & 2,000 & 4,857 & 493 & $\sqrt{ }$ & - \\
\hline & 9 & 1,379 & 0,962 & 2225 & - & $\sqrt{ }$ \\
\hline
\end{tabular}

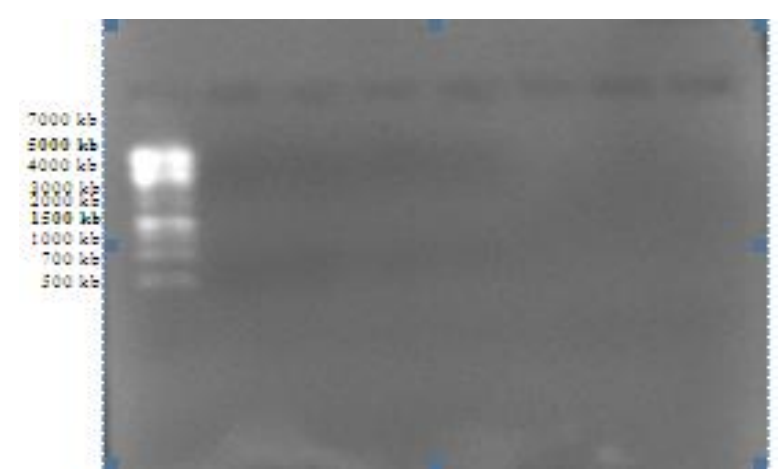

Gambar 1. Hasil isolasi DNA tanaman markisa menggunakan protokol A

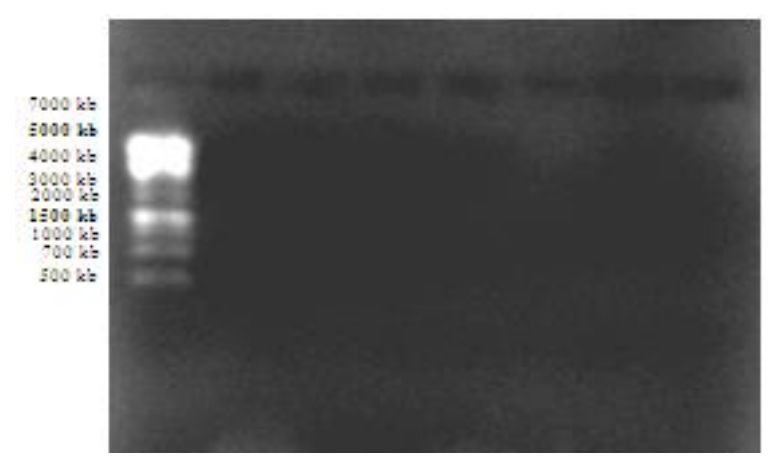

Gambar 2. Hasil isolasi DNA tanaman markisa menggunakan protokol B

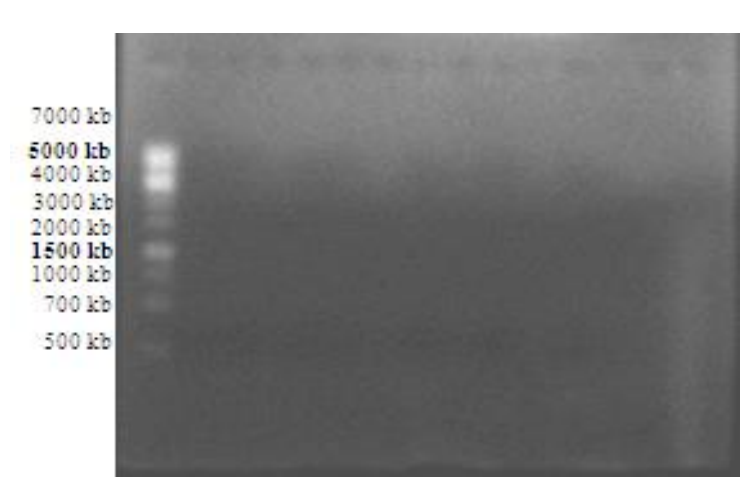

Gambar 3. Hasil isolasi DNA tanaman markisa menggunakan protokol C

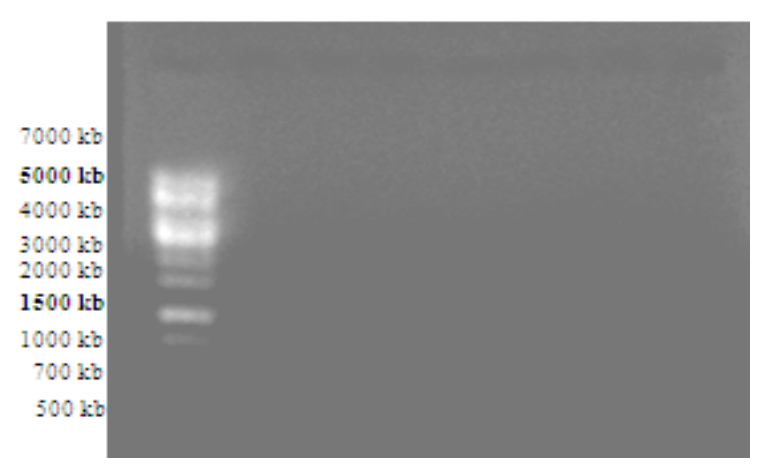

Gambar 4. Hasil isolasi DNA tanaman markisa menggunakan protokol D

Diterbitkan Oleh,

Unit Penelitian dan Pengabdian Masyarakat, Politeknik Pembangunan Pertanian Gowa

http://ejournal.polbangtan-gowa.ac.id 


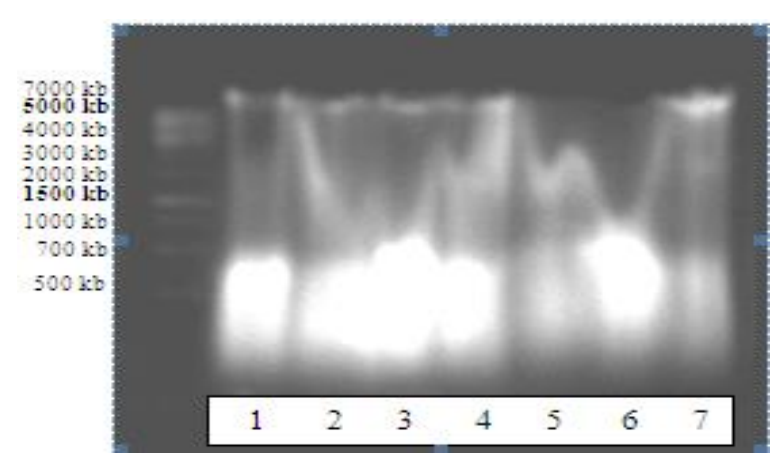

Gambar 5. Hasil isolasi DNA tanaman markisa menggunakan protokol $\mathrm{E}$

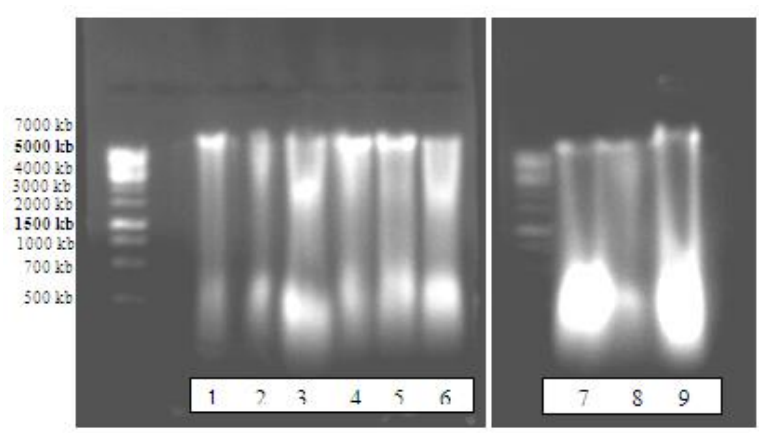

Gambar 6. Hasil isolasi DNA tanaman markisa menggunakan protokol $\mathrm{F}$

Berdasarkan hasil uji kuantitas dan kualitas DNA hasil ekstraksi tanaman markisa dataran rendah pada tabel 2 dan gambar 1, metode A merupakan metode yang kurang dapat menghasilkan kuantitas dan kualitas DNA yang baik karena dari sembilan sampel yang diuji dengan metode A hanya sampel ke-6 yang memiliki kemurnian yang baik, yaitu 1,842 pada rasio serapan A260/A280. Sedangkan untuk nilai rasio serapan A260/A230, tidak terdapat sampel yang menunjukkan angka diatas 1,600. Sedangkan konsentrasi yang dimiliki setiap sampel berkisar 21,9 - $186 \mu \mathrm{g} / \mathrm{mL}$. Rasio serapan A260/A280 dari 8 sampel menunjukkan angka yang rendah $(<1,8)$ (tabel 2) dan tidak munculnya pita DNA setelah dielektroforesis (gambar 1) menunjukkan bahwa kualitas dan kuantitas DNA markisa menggunakan metode A tergolong rendah. Nilai rasio serapan A260/A280 < 1,8 menunjukkan bahwa konsentrasi protein tinggi pada hasil isolasi DNA sehingga kemurnian hasil isolasi menjadi rendah dan tidak terlihat pita setelah dilakukannya elektroforesis. Seperti dijelaskan dalam Sambrook et al. (1989) bahwa DNA dikatakan murni apabila mempunyai angka A260/A280 dalam kisaran 1,8 - 2,0.
Pada metode A, suhu inkubasi yang tinggi dalam waktu yang cukup lama diperkirakan dapat merusak DNA tanaman markisa tersebut. Selain itu, kecepatan setrifugasi yang rendah mengakibatkan DNA yang diperoleh sangat sedikit dan memperoleh protein yang cukup banyak setelah dilakukannya ekstraksi, sehingga hasil uji kemurnian DNAnya tergolong rendah, dapat dikatakan $88,89 \%$ sampel pada metode A menunjukkan angka rasio serapan di bawah angka 1,8 (tabel 2). Hal ini sesuai dengan pendapat Santella (2006), rasio absorbansi pada panjang gelombang 260 dan 280 (A260/A280) berada di atas kisaran nilai DNA murni menunjukkan terdapat kontaminasi RNA, sedangkan rasio di bawah 1,8 menunjukkan masih terdapat kontaminasi protein.

Pada metode B, hasil isolasi DNA menunjukkan hal yang sama dengan sampel pada metode A. Terdapat hanya satu dari sembilan sampel yang diuji pada metode $B$ yang menunjukkan nilai murni pada rasio serapan A260/A280 (tabel 2). Namun tidak terdapat satupun sampel yang menunjukkan pita DNA setelah dilakukannya elektroforesis walaupun berat sampel daun ditingkatkan menjadi 0,200 gram (gambar 2). Hal ini menunjukkan bahwa metode A dan B tidak tepat digunakan untuk mengisolasi DNA markisa dataran rendah kabupaten Jeneponto.

Pada metode $\mathrm{C}$, hasil uji isolasi DNA menunjukkan nilai rasio serapan A260/A280 yang rendah (dibawah angka 1,8 ) dan rasio serapan A260/A230 di bawah angka 1,6 (tabel 2) serta tidak munculnya pita DNA setelah dielektroforesis (gambar 3). Berdasarkan hasil uji ini, sampel diperkirakan diinkubasi pada suhu yang cukup tinggi dan waktu yang inkubasi yang digunakan cukup cepat, sehingga larutan buffer CTAB tidak bekerja dengan baik pada sampel. Hal ini sesuai dengan pendapat Walker dan Rapley (2008), penggunaan 2-mercaptoethanol pada buffer CTAB dengan pemanasan juga dapat mendenaturasi protein yang mengkontaminasi DNA. Oleh karena itu, suhu $75^{\circ} \mathrm{C}$ diperkirakan tidak dapat memaksimalkan kerja buffer CTAB untuk mendenaturasi protein. Kecepatan sentrifugasi yang rendah juga diperkirakan tidak dapat memperoleh DNA yang terpisah dari protein dan RNA. Hal ini seperti yang dikatakan oleh Yuwono (2009) bahwa teknik sentrifugasi keseimbangan gradient densitas dapat digunakan untuk memisahkan molekul protein, DNA, dan 
RNA yang densitasnya dalam larutan $\mathrm{CsCl}$ berturut-turut adalah 1,$3 ; 1,6-1,7$; dan 1,75-1,8 $\mathrm{g} / \mathrm{ml}$. DNA mempunyai kerapatan yang sama dengan larutan sesium klorid $(\mathrm{CsCl})$, yakni sekitar $1,7 \mathrm{~g} / \mathrm{cm} 3$. Jika larutan ini disentrifugasi dengan kecepatan yang sangat tinggi, maka garam $\mathrm{CsCl}$ yang pekat akan bermigrasi ke dasar tabung dengan membentuk gradien kerapatan.

Pada metode D, hasil isolasi masih tidak menunjukkan DNA yang murni pada 8 sampel (tabel 2) dan tidak memperlihatkan pita DNA setelah dielektroforesis (gambar 4). Hal ini diperkirakan karena lama sentrifugasi 15 menit tidak efektif dalam memisahkan DNA dari protein dan RNA. Sentrifugasi yang lama dapat menghambat berkumpulnya DNA yang murni dari protein dan RNA.

Pada metode E, hasil isolasi mulai menunjukkan pita DNA yang tipis namun smear (gambar 5) dan masih menunjukkan rendahnya tingkat kemurnian DNA yang dihasilkan (tabel 2). Hal ini terjadi diperkirakan karena berat sampel daun yang tidak cukup untuk menghasilkan DNA yang cukup sehingga pada saat dielektroforesis, pita DNA sangat tipis bahkan tsulit untuk diukur dan diikuti oleh bayangan (smear) yang diperkirakan adalah RNA. Sehingga pada metode F, berat sampel daun ditingkatkan menjadi 0,200 gram, dan hasil uji menunjukkan bahwa pita DNA mulai terlihat menebal berkisar 2000 - $7000 \mathrm{~kb}$ (gambar 6) dan terdapat empat sampel menunjukkan angka rasio serapan A260/A280 berkisar antara 1,8 - 2,0 yang merupakan rasio yang dapat dikatakan bahwa DNA yang dikandung memiliki tingkat kemurnian yang cukup baik (tabel 2). Seperti dijelaskan dalam Sambrook et al. (1989) bahwa DNA dikatakan murni apabila mempunyai angka A260/A280 dalam kisaran 1,8 - 2,0. Hasil uji 7 sampel pada metode $\mathrm{F}$ juga memiliki nilai rasio serapan A260/230 $\geq 1$ menunjukkan bahwa hasil isolasi murni dari polisakarida. Menurut Moller et al. (1992), rasio serapan A260/280 $\geq 1,80$ menunjukkan bahwa DNA murni dari protein sedangkan rasio A260/230 $\geq 1,00$ menunjukkan bahwa DNA murni dari polisakarida.

\section{KESIMPULAN}

Berdasarkan hasil uji sampel pada beberapa metode yang telah diperoleh dan pembahasan di atas, dapat disimpulkan bahwa: metode $\mathrm{F}$ merupakan metode yang baik digunakan untuk mengisolasi DNA daun tanaman markisa dataran rendah kabupaten Jeneponto. Berat sampel sebesar 0,200 gram, suhu inkubasi hasil ekstraksi pada suhu $65^{\circ} \mathrm{C}$ selama 30 menit, dan kecepatan sentrifugasi sebesar $12.000 \mathrm{rpm}$ selama 10 menit dapat menghasilkan DNA yang memiliki kemurnian yang cukup baik dan tampak pita DNA yang cukup tebal berkisar $2000-7000 \mathrm{~kb}$ setelah hasil isolasi dielektroforesis. Sedangkan pemurnian kembali menggunakan kloroform: isoamylalkohol, isopropanol, dan ethanol $70 \%$ menunjukkan kualitas dan kuantitas DNA yang cukup baik pada sampel metode F.

\section{DAFTAR PUSTAKA}

Ardiana, Dwi Wahyuni. 2009. Teknik Isolasi DNA Genom Tanaman Pepaya dan Jeruk dengan Menggunakan Modifikasi Buffer CTAB. Buletin Teknik Pertanian Vol. 14 No. 1, 2009: 12-16

Barus, A., Syukri. 2008. Agroteknologi Tanaman Buah-Buahan. USU Press. Medan.

Chawla, H. S. 2003. Plant Biotechnology : A Practical Approach. Science Publishers, Inc. Plymouth

Fatchiyah, 2011. Modul Pelatihan Analisis Fingerprinting DNA Tanaman Dengan Metode RAPD. Laboratorium Sentral Ilmu Hayati Universitas Brawijaya, Malang.

Karp, A., S. Kresovich, K.V. Bhat, W.G. Ayad, and T. Hodgkin. 1997. Molecular Tool in Plant Genetic Resources Conservation: A guide to the technologies. IPGRI Technical Bulletin no. 2.

Karsinah, Silalahi F.H., Manshur A. 2007. Eksplorasi dan Karakteristik Plasma Nutrfah Tanaman Markisa.Badan Puslitbang Pertanian. Sumatera Utara.

Moller, E. M., Bahnweg, G., Sandermann, H. \& Geiger, H. H. (1992). A simple and efficient protocol for isolation of high molecular weight DNA from filamentous fungi, fruit bodies, and infected plant tissues. Nucleic Acids Res 20, 61156116

Rukmana, R. 2003. Usaha Tani Markisa. Kanisisus. Yogyakarta.

Sambrook, J., Fritsch, E.F \& Maniatis, T. 1989. MolecularCloning. A Laboratory 
Walker, John M., Rapley, Ralph. 2008. Molecular Biomethods.Humana press $\mathrm{xx}$.

Yuwono, Triwibowo. 2009. Biologi Molekuler. Jakarta: Erlangga. 